\title{
LORD ARTHUR SAVILE'S CRIME
}

Oscar Wilde

Gothic Digital Series @ UFSC

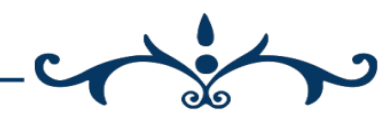


Chapter I

Chapter II

Chapter III

Chapter IV

Chapter V

Chapter VI 


\section{Lord Arthur SAVILE's CRime}

Oscar Wilde

(1891)

\section{Chapter I}

IT was Lady Windermere's last reception before Easter, and Bentinck House was even more crowded than usual. Six Cabinet Ministers had come on from the Speaker's Levée in their stars and ribands, all the pretty women wore their smartest dresses, and at the end of the picture-gallery stood the Princess Sophia of Carlsrühe, a heavy Tartar-looking lady, with tiny black eyes and wonderful emeralds, talking bad French at the top of her voice, and laughing immoderately at everything that was said to her. It was certainly a wonderful medley of people. Gorgeous peeresses chatted affably to violent Radicals, popular preachers brushed coat-tails with eminent sceptics, a perfect bevy of bishops kept following a stout prima-donna from room to room, on the staircase stood several Royal Academicians, disguised as artists, and it was said that at one time the supper-room was absolutely crammed with geniuses. In fact, it was one of Lady Windermere's best nights, and the Princess stayed till nearly half-past eleven.

As soon as she had gone, Lady Windermere returned to the picture-gallery, where a celebrated political economist was solemnly explaining the scientific theory of music to an indignant virtuoso from Hungary, and began to talk to the Duchess of Paisley. She looked wonderfully beautiful with her grand ivory throat, her large blue forget-me-not eyes, and her heavy coils of golden hair. Or pur they were - not that pale straw colour that nowadays usurps the gracious name of gold, but such gold as is woven into sunbeams or hidden in strange amber; and they gave to her face something of the frame of a saint, with not a little of the fascination of a sinner. She was a curious psychological study. Early in life she had discovered the important truth that nothing looks so like innocence as an indiscretion; and by a series of reckless escapades, half of them quite harmless, she had acquired all the privileges of a personality. She had more than once changed her husband; indeed, Debrett credits her with three marriages; but as she had never changed her lover, the world had long ago ceased to talk scandal about her. She was now forty years of age, childless, and with that inordinate passion for pleasure which is the secret of remaining young.

Suddenly she looked eagerly round the room, and said, in her clear contralto voice, "Where is my cheiromantist?"

"Your what, Gladys?" exclaimed the Duchess, giving an involuntary start.

"My cheiromantist, Duchess; I can't live without him at present." 
"Dear Gladys! you are always so original," murmured the Duchess, trying to remember what a cheiromantist really was, and hoping it was not the same as a cheiropodist.

"He comes to see my hand twice a week regularly," continued Lady Windermere, "and is most interesting about it."

"Good heavens!" said the Duchess to herself, "he is a sort of cheiropodist after all. How very dreadful. I hope he is a foreigner at any rate. It wouldn't be quite so bad then."

"I must certainly introduce him to you."

"Introduce him!" cried the Duchess; "you don't mean to say he is here?" and she began looking about for a small tortoise-shell fan and a very tattered lace shawl, so as to be ready to go at a moment's notice.

"Of course he is here; I would not dream of giving a party without him. He tells me I have a pure psychic hand, and that if my thumb had been the least little bit shorter, I should have been a confirmed pessimist, and gone into a convent."

"Oh, I see!" said the Duchess, feeling very much relieved; "he tells fortunes, I suppose?"

"And misfortunes, too," answered Lady Windermere, "any amount of them. Next year, for instance, I am in great danger, both by land and sea, so I am going to live in a balloon, and draw up my dinner in a basket every evening. It is all written down on my little finger, or on the palm of my hand, I forget which."

"But surely that is tempting Providence, Gladys."

"My dear Duchess, surely Providence can resist temptation by this time. I think every one should have their hands told once a month, so as to know what not to do. Of course, one does it all the same, but it is so pleasant to be warned. Now if some one doesn't go and fetch Mr. Podgers at once, I shall have to go myself."

"Let me go, Lady Windermere," said a tall handsome young man, who was standing by, listening to the conversation with an amused smile.

"Thanks so much, Lord Arthur; but I am afraid you wouldn't recognise him."

"If he is as wonderful as you say, Lady Windermere, I couldn't well miss him. Tell me what he is like, and I'll bring him to you at once."

"Well, he is not a bit like a cheiromantist. I mean he is not mysterious, or esoteric, or romantic-looking. He is a little, stout man, with a funny, bald head, and great goldrimmed spectacles; something between a family doctor and a country attorney. I'm really very sorry, but it is not my fault. People are so annoying. All my pianists look exactly like poets, and all my poets look exactly like pianists; and I remember last season asking a most dreadful conspirator to dinner, a man who had blown up ever so many people, and always wore a coat of mail, and carried a dagger up his shirt-sleeve; and do you know that when he came he looked just like a nice old clergyman, and cracked jokes all the evening? Of course, he was very amusing, and all that, but I was awfully disappointed; and when I asked him about the coat of mail, he only laughed, and said it was far too cold to wear in England. Ah, here is Mr. Podgers! Now, Mr. 
Podgers, I want you to tell the Duchess of Paisley's hand. Duchess, you must take your glove off. No, not the left hand, the other."

"Dear Gladys, I really don't think it is quite right," said the Duchess, feebly unbuttoning a rather soiled kid glove.

"Nothing interesting ever is," said Lady Windermere: "on a fait le monde ainsi. But I must introduce you. Duchess, this is Mr. Podgers, my pet cheiromantist. Mr. Podgers, this is the Duchess of Paisley, and if you say that she has a larger mountain of the moon than I have, I will never believe in you again."

"I am sure, Gladys, there is nothing of the kind in my hand," said the Duchess gravely.

"Your Grace is quite right," said Mr. Podgers, glancing at the little fat hand with its short square fingers, "the mountain of the moon is not developed. The line of life, however, is excellent. Kindly bend the wrist. Thank you. Three distinct lines on the rascette! You will live to a great age, Duchess, and be extremely happy. Ambition - very moderate, line of intellect not exaggerated, line of heart -"

"Now, do be indiscreet, Mr. Podgers," cried Lady Windermere.

"Nothing would give me greater pleasure," said Mr. Podgers, bowing, "if the Duchess ever had been, but I am sorry to say that I see great permanence of affection, combined with a strong sense of duty."

"Pray go on, Mr. Podgers," said the Duchess, looking quite pleased.

"Economy is not the least of your Grace's virtues," continued Mr. Podgers, and Lady Windermere went off into fits of laughter.

"Economy is a very good thing," remarked the Duchess complacently; "when I married Paisley he had eleven castles, and not a single house fit to live in."

"And now he has twelve houses, and not a single castle," cried Lady Windermere.

"Well, my dear," said the Duchess, "I like -"

"Comfort," said Mr. Podgers, "and modern improvements, and hot water laid on in every bedroom. Your Grace is quite right. Comfort is the only thing our civilisation can give us."

"You have told the Duchess's character admirably, Mr. Podgers, and now you must tell Lady Flora's"; and in answer to a nod from the smiling hostess, a tall girl, with sandy Scotch hair, and high shoulder-blades, stepped awkwardly from behind the sofa, and held out a long, bony hand with spatulate fingers.

"Ah, a pianist! I see," said Mr. Podgers, "an excellent pianist, but perhaps hardly a musician. Very reserved, very honest, and with a great love of animals."

"Quite true!" exclaimed the Duchess, turning to Lady Windermere, "absolutely true! Flora keeps two dozen collie dogs at Macloskie, and would turn our town house into a menagerie if her father would let her."

"Well, that is just what I do with my house every Thursday evening," cried Lady Windermere, laughing, "only I like lions better than collie dogs."

"Your one mistake, Lady Windermere," said Mr. Podgers, with a pompous bow. 
"If a woman can't make her mistakes charming, she is only a female," was the answer. "But you must read some more hands for us. Come, Sir Thomas, show Mr. Podgers yours"; and a genial-looking old gentleman, in a white waistcoat, came forward, and held out a thick rugged hand, with a very long third finger.

"An adventurous nature; four long voyages in the past, and one to come. Been ship-wrecked three times. No, only twice, but in danger of a shipwreck your next journey. A strong Conservative, very punctual, and with a passion for collecting curiosities. Had a severe illness between the ages sixteen and eighteen. Was left a fortune when about thirty. Great aversion to cats and Radicals."

"Extraordinary!" exclaimed Sir Thomas; "you must really tell my wife's hand, too."

"Your second wife's," said Mr. Podgers quietly, still keeping Sir Thomas's hand in his. "Your second wife's. I shall be charmed"; but Lady Marvel, a melancholy-looking woman, with brown hair and sentimental eyelashes, entirely declined to have her past or her future exposed; and nothing that Lady Windermere could do would induce Monsieur de Koloff, the Russian Ambassador, even to take his gloves off. In fact, many people seemed afraid to face the odd little man with his stereotyped smile, his gold spectacles, and his bright, beady eyes; and when he told poor Lady Fermor, right out before every one, that she did not care a bit for music, but was extremely fond of musicians, it was generally felt that cheiromancy was a most dangerous science, and one that ought not to be encouraged, except in a tête-à-tête.

Lord Arthur Savile, however, who did not know anything about Lady Fermor's unfortunate story, and who had been watching Mr. Podgers with a great deal of interest, was filled with an immense curiosity to have his own hand read, and feeling somewhat shy about putting himself forward, crossed over the room to where Lady Windermere was sitting, and, with a charming blush, asked her if she thought Mr. Podgers would mind.

"Of course, he won't mind," said Lady Windermere, "that is what he is here for. All my lions, Lord Arthur, are performing lions, and jump through hoops whenever I ask them. But I must warn you beforehand that I shall tell Sybil everything. She is coming to lunch with me tomorrow, to talk about bonnets, and if Mr. Podgers finds out that you have a bad temper, or a tendency to gout, or a wife living in Bayswater, I shall certainly let her know all about it."

Lord Arthur smiled, and shook his head. "I am not afraid," he answered. "Sybil knows me as well as I know her."

"Ah! I am a little sorry to hear you say that. The proper basis for marriage is a mutual misunderstanding. No, I am not at all cynical, I have merely got experience, which, however, is very much the same thing. Mr. Podgers, Lord Arthur Savile is dying to have his hand read. Don't tell him that he is engaged to one of the most beautiful girls in London, because that appeared in the Morning Post a month ago."

"Dear Lady Windermere," cried the Marchioness of Jedburgh, "do let Mr. Podgers stay here a little longer. He has just told me I should go on the stage, and I am so interested." 
"If he has told you that, Lady Jedburgh, I shall certainly take him away. Come over at once, Mr. Podgers, and read Lord Arthur's hand."

"Well," said Lady Jedburgh, making a little moue as she rose from the sofa, "if I am not to be allowed to go on the stage, I must be allowed to be part of the audience at any rate."

"Of course; we are all going to be part of the audience," said Lady Windermere; "and now, Mr. Podgers, be sure and tell us something nice. Lord Arthur is one of my special favourites."

But when Mr. Podgers saw Lord Arthur's hand he grew curiously pale, and said nothing. A shudder seemed to pass through him, and his great bushy eyebrows twitched convulsively, in an odd, irritating way they had when he was puzzled. Then some huge beads of perspiration broke out on his yellow forehead, like a poisonous dew, and his fat fingers grew cold and clammy.

Lord Arthur did not fail to notice these strange signs of agitation, and, for the first time in his life, he himself felt fear. His impulse was to rush from the room, but he restrained himself. It was better to know the worst, whatever it was, than to be left in this hideous uncertainty.

"I am waiting, Mr. Podgers," he said.

"We are all waiting," cried Lady Windermere, in her quick, impatient manner, but the cheiromantist made no reply.

"I believe Arthur is going on the stage," said Lady Jedburgh, "and that, after your scolding, Mr. Podgers is afraid to tell him so."

Suddenly Mr. Podgers dropped Lord Arthur's right hand, and seized hold of his left, bending down so low to examine it that the gold rims of his spectacles seemed almost to touch the palm. For a moment his face became a white mask of horror, but he soon recovered his sang-froid, and looking up at Lady Windermere, said with a forced smile, "It is the hand of a charming young man."

"Of course it is!" answered Lady Windermere, "but will he be a charming husband? That is what I want to know."

"All charming young men are," said Mr. Podgers.

"I don't think a husband should be too fascinating," murmured Lady Jedburgh pensively, "it is so dangerous."

"My dear child, they never are too fascinating," cried Lady Windermere. "But what I want are details. Details are the only things that interest. What is going to happen to Lord Arthur?"

"Well, within the next few months Lord Arthur will go a voyage -"

"Oh yes, his honeymoon, of course!"

"And lose a relative."

"Not his sister, I hope?" said Lady Jedburgh, in a piteous tone of voice.

"Certainly not his sister," answered Mr. Podgers, with a deprecating wave of the hand, "a distant relative merely." 
"Well, I am dreadfully disappointed," said Lady Windermere. "I have absolutely nothing to tell Sybil tomorrow. No one cares about distant relatives nowadays. They went out of fashion years ago. However, I suppose she had better have a black silk by her; it always does for church, you know. And now let us go to supper. They are sure to have eaten everything up, but we may find some hot soup. François used to make excellent soup once, but he is so agitated about politics at present, that I never feel quite certain about him. I do wish General Boulanger would keep quiet. Duchess, I am sure you are tired?"

"Not at all, dear Gladys," answered the Duchess, waddling towards the door. "I have enjoyed myself immensely, and the cheiropodist, I mean the cheiromantist, is most interesting. Flora, where can my tortoise-shell fan be? Oh, thank you, Sir Thomas, so much. And my lace shawl, Flora? Oh, thank you, Sir Thomas, very kind, I'm sure"; and the worthy creature finally managed to get downstairs without dropping her scent-bottle more than twice.

All this time Lord Arthur Savile had remained standing by the fireplace, with the same feeling of dread over him, the same sickening sense of coming evil. He smiled sadly at his sister, as she swept past him on Lord Plymdale's arm, looking lovely in her pink brocade and pearls, and he hardly heard Lady Windermere when she called to him to follow her. He thought of Sybil Merton, and the idea that anything could come between them made his eyes dim with tears.

Looking at him, one would have said that Nemesis had stolen the shield of Pallas, and shown him the Gorgon's head. He seemed turned to stone, and his face was like marble in its melancholy. He had lived the delicate and luxurious life of a young man of birth and fortune, a life exquisite in its freedom from sordid care, its beautiful boyish insouciance; and now for the first time he became conscious of the terrible mystery of Destiny, of the awful meaning of Doom.

How mad and monstrous it all seemed! Could it be that written on his hand, in characters that he could not read himself, but that another could decipher, was some fearful secret of sin, some blood-red sign of crime? Was there no escape possible? Were we no better than chessmen, moved by an unseen power, vessels the potter fashions at his fancy, for honour or for shame? His reason revolted against it, and yet he felt that some tragedy was hanging over him, and that he had been suddenly called upon to bear an intolerable burden. Actors are so fortunate. They can choose whether they will appear in tragedy or in comedy, whether they will suffer or make merry, laugh or shed tears. But in real life it is different. Most men and women are forced to perform parts for which they have no qualifications. Our Guildensterns play Hamlet for us, and our Hamlets have to jest like Prince Hal. The world is a stage, but the play is badly cast.

Suddenly Mr. Podgers entered the room. When he saw Lord Arthur he started, and his coarse, fat face became a sort of greenish-yellow colour. The two men's eyes met, and for a moment there was silence. 
"The Duchess has left one of her gloves here, Lord Arthur, and has asked me to bring it to her," said Mr. Podgers finally. "Ah, I see it on the sofa! Good evening."

"Mr. Podgers, I must insist on your giving me a straightforward answer to a question I am going to put to you."

"Another time, Lord Arthur, but the Duchess is anxious. I am afraid I must go."

"You shall not go. The Duchess is in no hurry."

"Ladies should not be kept waiting, Lord Arthur," said Mr. Podgers, with his sickly smile. "The fair sex is apt to be impatient."

Lord Arthur's finely-chiselled lips curled in petulant disdain. The poor Duchess seemed to him of very little importance at that moment. He walked across the room to where Mr. Podgers was standing, and held his hand out.

"Tell me what you saw there," he said. "Tell me the truth. I must know it. I am not a child."

Mr. Podgers's eyes blinked behind his gold-rimmed spectacles, and he moved uneasily from one foot to the other, while his fingers played nervously with a flash watch-chain.

"What makes you think that I saw anything in your hand, Lord Arthur, more than I told you?"

"I know you did, and I insist on your telling me what it was. I will pay you. I will give you a cheque for a hundred pounds."

The green eyes flashed for a moment, and then became dull again.

"Guineas?" said Mr. Podgers at last, in a low voice.

"Certainly. I will send you a cheque tomorrow. What is your club?"

"I have no club. That is to say, not just at present. My address is -, but allow me to give you my card"; and producing a bit of gilt-edge pasteboard from his waistcoat pocket, Mr. Podgers handed it, with a low bow, to Lord Arthur, who read on it,

\section{Mr. SEPTIMUS R. PODGERS \\ Professional Cheiromantist \\ 103a West Moon Street}

"My hours are from ten to four," murmured Mr. Podgers mechanically, "and I make a reduction for families."

"Be quick," cried Lord Arthur, looking very pale, and holding his hand out.

Mr. Podgers glanced nervously round, and drew the heavy portière across the door.

"It will take a little time, Lord Arthur, you had better sit down."

"Be quick, sir," cried Lord Arthur again, stamping his foot angrily on the polished floor.

Mr. Podgers smiled, drew from his breast-pocket a small magnifying glass, and wiped it carefully with his handkerchief.

"I am quite ready," he said. 


\section{Chapter II}

TEN minutes later, with face blanched by terror, and eyes wild with grief, Lord Arthur Savile rushed from Bentinck House, crushing his way through the crowd of fur-coated footmen that stood round the large striped awning, and seeming not to see or hear anything. The night was bitter cold, and the gas-lamps round the square flared and flickered in the keen wind; but his hands were hot with fever, and his forehead burned like fire. On and on he went, almost with the gait of a drunken man. A policeman looked curiously at him as he passed, and a beggar, who slouched from an archway to ask for alms, grew frightened, seeing misery greater than his own. Once he stopped under a lamp, and looked at his hands. He thought he could detect the stain of blood already upon them, and a faint cry broke from his trembling lips.

Murder! that is what the cheiromantist had seen there. Murder! The very night seemed to know it, and the desolate wind to howl it in his ear. The dark corners of the streets were full of it. It grinned at him from the roofs of the houses.

First he came to the Park, whose sombre woodland seemed to fascinate him. He leaned wearily up against the railings, cooling his brow against the wet metal, and listening to the tremulous silence of the trees. "Murder! murder!" he kept repeating, as though iteration could dim the horror of the word. The sound of his own voice made him shudder, yet he almost hoped that Echo might hear him, and wake the slumbering city from its dreams. He felt a mad desire to stop the casual passer-by, and tell him everything.

Then he wandered across Oxford Street into narrow, shameful alleys. Two women with painted faces mocked at him as he went by. From a dark courtyard came a sound of oaths and blows, followed by shrill screams, and, huddled upon a damp door-step, he saw the crook-backed forms of poverty and eld. A strange pity came over him. Were these children of sin and misery predestined to their end, as he to his? Were they, like him, merely the puppets of a monstrous show?

And yet it was not the mystery, but the comedy of suffering that struck him; its absolute uselessness, its grotesque want of meaning. How incoherent everything seemed! How lacking in all harmony! He was amazed at the discord between the shallow optimism of the day, and the real facts of existence. He was still very young.

After a time he found himself in front of Marylebone Church. The silent roadway looked like a long riband of polished silver, flecked here and there by the dark arabesques of waving shadows. Far into the distance curved the line of flickering gaslamps, and outside a little walled-in house stood a solitary hansom, the driver asleep inside. He walked hastily in the direction of Portland Place, now and then looking round, as though he feared that he was being followed. At the corner of Rich Street stood two men, reading a small bill upon a hoarding. An odd feeling of curiosity stirred him, and he crossed over. As he came near, the word "Murder," printed in black letters, met his eye. He started, and a deep flush came into his cheek. It was an advertisement offering a reward for any information leading to the arrest of a man of 
medium height, between thirty and forty years of age, wearing a billy-cock hat, a black coat, and check trousers, and with a scar upon his right cheek. He read it over and over again, and wondered if the wretched man would be caught, and how he had been scarred. Perhaps, some day, his own name might be placarded on the walls of London. Some day, perhaps, a price would be set on his head also.

The thought made him sick with horror. He turned on his heel, and hurried on into the night.

Where he went he hardly knew. He had a dim memory of wandering through a labyrinth of sordid houses, of being lost in a giant web of sombre streets, and it was bright dawn when he found himself at last in Piccadilly Circus. As he strolled home towards Belgrave Square, he met the great waggons on their way to Covent Garden. The white-smocked carters, with their pleasant sunburnt faces and coarse curly hair, strode sturdily on, cracking their whips, and calling out now and then to each other; on the back of a huge grey horse, the leader of a jangling team, sat a chubby boy, with a bunch of primroses in his battered hat, keeping tight hold of the mane with his little hands, and laughing; and the great piles of vegetables looked like masses of jade against the morning sky, like masses of green jade against the pink petals of some marvellous rose. Lord Arthur felt curiously affected, he could not tell why. There was something in the dawn's delicate loveliness that seemed to him inexpressibly pathetic, and he thought of all the days that break in beauty, and that set in storm. These rustics, too, with their rough, good-humoured voices, and their nonchalant ways, what a strange London they saw! A London free from the sin of night and the smoke of day, a pallid, ghost-like city, a desolate town of tombs! He wondered what they thought of it, and whether they knew anything of its splendour and its shame, of its fierce, fiery-coloured joys, and its horrible hunger, of all it makes and mars from morn to eve. Probably it was to them merely a mart where they brought their fruits to sell, and where they tarried for a few hours at most, leaving the streets still silent, the houses still asleep. It gave him pleasure to watch them as they went by. Rude as they were, with their heavy, hob-nailed shoes, and their awkward gait, they brought a little of a ready with them. He felt that they had lived with Nature, and that she had taught them peace. He envied them all that they did not know.

By the time he had reached Belgrave Square the sky was a faint blue, and the birds were beginning to twitter in the gardens.

\section{Chapter III}

WHEN Lord Arthur woke it was twelve o'clock, and the midday sun was streaming through the ivory-silk curtains of his room. He got up and looked out of the window. A dim haze of heat was hanging over the great city, and the roofs of the houses were like dull silver. In the flickering green of the square below some children were flitting about like white butterflies, and the pavement was crowded with people on their way 
to the Park. Never had life seemed lovelier to him, never had the things of evil seemed more remote.

Then his valet brought him a cup of chocolate on a tray. After he had drunk it, he drew aside a heavy portière of peach-coloured plush, and passed into the bathroom. The light stole softly from above, through thin slabs of transparent onyx, and the water in the marble tank glimmered like a moonstone. He plunged hastily in, till the cool ripples touched throat and hair, and then dipped his head right under, as though he would have wiped away the stain of some shameful memory. When he stepped out he felt almost at peace. The exquisite physical conditions of the moment had dominated him, as indeed often happens in the case of very finely-wrought natures, for the senses, like fire, can purify as well as destroy.

After breakfast, he flung himself down on a divan, and lit a cigarette. On the mantel-shelf, framed in dainty old brocade, stood a large photograph of Sybil Merton, as he had seen her first at Lady Noel's ball. The small, exquisitely-shaped head drooped slightly to one side, as though the thin, reed-like throat could hardly bear the burden of so much beauty; the lips were slightly parted, and seemed made for sweet music; and all the tender purity of girlhood looked out in wonder from the dreaming eyes. With her soft, clinging dress ofcrêpe-de-chine, and her large leafshaped fan, she looked like one of those delicate little figures men find in the olivewoods near Tanagra; and there was a touch of Greek grace in her pose and attitude. Yet she was not petite. She was simply perfectly proportioned - a rare thing in an age when so many women are either over life-size or insignificant.

Now as Lord Arthur looked at her, he was filled with the terrible pity that is born of love. He felt that to marry her, with the doom of murder hanging over his head, would be a betrayal like that of Judas, a sin worse than any the Borgia had ever dreamed of. What happiness could there be for them, when at any moment he might be called upon to carry out the awful prophecy written in his hand? What manner of life would be theirs while Fate still held this fearful fortune in the scales? The marriage must be postponed, at all costs. Of this he was quite resolved. Ardently though he loved the girl, and the mere touch of her fingers, when they sat together, made each nerve of his body thrill with exquisite joy, he recognised none the less clearly where his duty lay, and was fully conscious of the fact that he had no right to marry until he had committed the murder. This done, he could stand before the altar with Sybil Merton, and give his life into her hands without terror of wrongdoing. This done, he could take her to his arms, knowing that she would never have to blush for him, never have to hang her head in shame. But done it must be first; and the sooner the better for both.

Many men in his position would have preferred the primrose path of dalliance to the steep heights of duty; but Lord Arthur was too conscientious to set pleasure above principle. There was more than mere passion in his love; and Sybil was to him a symbol of all that is good and noble. For a moment he had a natural repugnance against what he was asked to do, but it soon passed away. His heart told him that it 
was not a sin, but a sacrifice; his reason reminded him that there was no other course open. He had to choose between living for himself and living for others, and terrible though the task laid upon him undoubtedly was, yet he knew that he must not suffer selfishness to triumph over love. Sooner or later we are all called upon to decide on the same issue - of us all, the same question is asked. To Lord Arthur it came early in life - before his nature had been spoiled by the calculating cynicism of middle-age, or his heart corroded by the shallow, fashionable egotism of our day, and he felt no hesitation about doing his duty. Fortunately also, for him, he was no mere dreamer, or idle dilettante. Had he been so, he would have hesitated, like Hamlet, and let irresolution mar his purpose. But he was essentially practical. Life to him meant action, rather than thought. He had that rarest of all things, common sense.

The wild, turbid feelings of the previous night had by this time completely passed away, and it was almost with a sense of shame that he looked back upon his mad wanderings from street to street, his fierce emotional agony. The very sincerity of his sufferings made them seem unreal to him now. He wondered how he could have been so foolish as to rant and rave about the inevitable. The only question that seemed to trouble him was, whom to make away with; for he was not blind to the fact that murder, like the religions of the Pagan world, requires a victim as well as a priest. Not being a genius, he had no enemies, and indeed he felt that this was not the time for the gratification of any personal pique or dislike, the mission in which he was engaged being one of great and grave solemnity. He accordingly made out a list of his friends and relatives on a sheet of notepaper, and after careful consideration, decided in favour of Lady Clementina Beauchamp, a dear old lady who lived in Curzon Street, and was his own second cousin by his mother's side. He had always been very fond of Lady Clem, as every one called her, and as he was very wealthy himself, having come into all Lord Rugby's property when he came of age, there was no possibility of his deriving any vulgar monetary advantage by her death. In fact, the more he thought over the matter, the more she seemed to him to be just the right person, and, feeling that any delay would be unfair to Sybil, he determined to make his arrangements at once.

The first thing to be done was, of course, to settle with the cheiromantist; so he sat down at a small Sheraton writing-table that stood near the window, drew a cheque for $£ 105$, payable to the order of Mr. Septimus Podgers, and, enclosing it in an envelope, told his valet to take it to West Moon Street. He then telephoned to the stables for his hansom, and dressed to go out. As he was leaving the room he looked back at Sybil Merton's photograph, and swore that, come what may, he would never let her know what he was doing for her sake, but would keep the secret of his selfsacrifice hidden always in his heart.

On his way to the Buckingham, he stopped at a florist's, and sent Sybil a beautiful basket of narcissus, with lovely white petals and staring pheasants' eyes, and on arriving at the club, went straight to the library, rang the bell, and ordered the waiter to bring him a lemon-and-soda, and a book on Toxicology. He had fully decided that 
poison was the best means to adopt in this troublesome business. Anything like personal violence was extremely distasteful to him, and besides, he was very anxious not to murder Lady Clementina in any way that might attract public attention, as he hated the idea of being lionised at Lady Windermere's, or seeing his name figuring in the paragraphs of vulgar society - newspapers. He had also to think of Sybil's father and mother, who were rather old-fashioned people, and might possibly object to the marriage if there was anything like a scandal, though he felt certain that if he told them the whole facts of the case they would be the very first to appreciate the motives that had actuated him. He had every reason, then, to decide in favour of poison. It was safe, sure, and quiet, and did away with any necessity for painful scenes, to which, like most Englishmen, he had a rooted objection.

Of the science of poisons, however, he knew absolutely nothing, and as the waiter seemed quite unable to find anything in the library but Ruff's Guide and Bailey's Magazine, he examined the book-shelves himself, and finally came across a handsomely-bound edition of the Pharmacopoeia, and a copy of Erskine's Toxicology, edited by Sir Mathew Reid, the President of the Royal College of Physicians, and one of the oldest members of the Buckingham, having been elected in mistake for somebody else; a contretemps that so enraged the Committee, that when the real man came up they black-balled him unanimously. Lord Arthur was a good deal puzzled at the technical terms used in both books, and had begun to regret that he had not paid more attention to his classics at Oxford, when in the second volume of Erskine, he found a very interesting and complete account of the properties of aconitine, written in fairly clear English. It seemed to him to be exactly the poison he wanted. It was swift - indeed, almost immediate, in its effect - perfectly painless, and when taken in the form of a gelatine capsule, the mode recommended by Sir Mathew, not by any means unpalatable. He accordingly made a note, upon his shirt-cuff, of the amount necessary for a fatal dose, put the books back in their places, and strolled up St. James's Street, to Pestle and Humbey's, the great chemists. Mr. Pestle, who always attended personally on the aristocracy, was a good deal surprised at the order, and in a very deferential manner murmured something about a medical certificate being necessary. However, as soon as Lord Arthur explained to him that it was for a large Norwegian mastiff that he was obliged to get rid of, as it showed signs of incipient rabies, and had already bitten the coachman twice in the calf of the leg, he expressed himself as being perfectly satisfied, complimented Lord Arthur on his wonderful knowledge of Toxicology, and had the prescription made up immediately.

Lord Arthur put the capsule into a pretty little silver bonbonnière that he saw in a shop window in Bond Street, threw away Pestle and Hambey's ugly pill-box, and drove off at once to Lady Clementina's.

"Well, monsieur le mauvais sujet," cried the old lady, as he entered the room, "why haven't you been to see me all this time?"

"My dear Lady Clem, I never have a moment to myself," said Lord Arthur, smiling. 
"I suppose you mean that you go about all day long with Miss Sybil Merton, buying chiffons and talking nonsense? I cannot understand why people make such a fuss about being married. In my day we never dreamed of billing and cooing in public, or in private for that matter."

"I assure you I have not seen Sybil for twenty-four hours, Lady Clem. As far as I can make out, she belongs entirely to her milliners."

"Of course; that is the only reason you come to see an ugly old woman like myself. I wonder you men don't take warning. On a fait des folies pour moi, and here I am, a poor rheumatic creature, with a false front and a bad temper. Why, if it were not for dear Lady Jansen, who sends me all the worst French novels she can find, I don't think I could get through the day. Doctors are no use at all, except to get fees out of one. They can't even cure my heartburn."

"I have brought you a cure for that, Lady Clem," said Lord Arthur gravely. "It is a wonderful thing, invented by an American."

"I don't think I like American inventions, Arthur. I am quite sure I don't. I read some American novels lately, and they were quite nonsensical."

"Oh, but there is no nonsense at all about this, Lady Clem! I assure you it is a perfect cure. You must promise to try it"; and Lord Arthur brought the little box out of his pocket, and handed it to her.

"Well, the box is charming, Arthur. Is it really a present? That is very sweet of you. And is this the wonderful medicine? It looks like a bonbon. I'll take it at once."

"Good heavens! Lady Clem," cried Lord Arthur, catching hold of her hand, "you mustn't do anything of the kind. It is a homoeopathic medicine, and if you take it without having heartburn, it might do you no end of harm. Wait till you have an attack, and take it then. You will be astonished at the result."

"I should like to take it now," said Lady Clementina, holding up to the light the little transparent capsule, with its floating bubble of liquid aconitine. "I am sure it is delicious. The fact is that, though I hate doctors, I love medicines. However, I'll keep it till my next attack."

"And when will that be?" asked Lord Arthur eagerly. "Will it be soon?"

"I hope not for a week. I had a very bad time yesterday morning with it. But one never knows."

"You are sure to have one before the end of the month then, Lady Clem?"

"I am afraid so. But how sympathetic you are today, Arthur! Really, Sybil has done you a great deal of good. And now you must run away, for I am dining with some very dull people, who won't talk scandal, and I know that if I don't get my sleep now I shall never be able to keep awake during dinner. Good-bye, Arthur, give my love to Sybil, and thank you so much for the American medicine."

"You won't forget to take it, Lady Clem, will you?" said Lord Arthur, rising from his seat.

"Of course I won't, you silly boy. I think it is most kind of you to think of me, and I shall write and tell you if I want any more." 
Lord Arthur left the house in high spirits, and with a feeling of immense relief.

That night he had an interview with Sybil Merton. He told her how he had been suddenly placed in a position of terrible difficulty, from which neither honour nor duty would allow him to recede. He told her that the marriage must be put off for the present, as until he had got rid of his fearful entanglements, he was not a free man. He implored her to trust him, and not to have any doubts about the future. Everything would come right, but patience was necessary.

The scene took place in the conservatory of Mr. Merton's house, in Park Lane, where Lord Arthur had dined as usual. Sybil had never seemed more happy, and for a moment Lord Arthur had been tempted to play the coward's part, to write to Lady Clementina for the pill, and to let the marriage go on as if there was no such person as Mr. Podgers in the world. His better nature, however, soon asserted itself, and even when Sybil flung herself weeping into his arms, he did not falter. The beauty that stirred his senses had touched his conscience also. He felt that to wreck so fair a life for the sake of a few months' pleasure would be a wrong thing to do.

He stayed with Sybil till nearly midnight, comforting her and being comforted in turn, and early the next morning he left for Venice, after writing a manly, firm letter to Mr. Merton about the necessary postponement of the marriage.

\section{Chapter IV}

IN Venice he met his brother, Lord Surbiton, who happened to have come over from Corfu in his yacht. The two young men spent a delightful fortnight together. In the morning they rode on the Lido, or glided up and down the green canals in their long black gondola; in the afternoon they usually entertained visitors on the yacht; and in the evening they dined at Florian's, and smoked innumerable cigarettes on the Piazza. Yet somehow Lord Arthur was not happy. Every day he studied the obituary column in the Times, expecting to see a notice of Lady Clementina's death, but every day he was disappointed. He began to be afraid that some accident had happened to her, and often regretted that he had prevented her taking the aconitine when she had been so anxious to try its effect. Sybil's letters, too, though full of love, and trust, and tenderness, were often very sad in their tone, and sometimes he used to think that he was parted from her for ever.

After a fortnight Lord Surbiton got bored with Venice, and determined to run down the coast to Ravenna, as he heard that there was some capital cock-shooting in the Pinetum. Lord Arthur at first refused absolutely to come, but Surbiton, of whom he was extremely fond, finally persuaded him that if he stayed at Danieli's by himself he would be moped to death, and on the morning of the 15th they started, with a strong nor'-east wind blowing, and a rather choppy sea. The sport was excellent, and the free, open-air life brought the colour back to Lord Arthur's cheek, but about the 22nd he became anxious about Lady Clementina, and, in spite of Surbiton's remonstrances, came back to Venice by train. 
As he stepped out of his gondola on to the hotel steps, the proprietor came forward to meet him with a sheaf of telegrams. Lord Arthur snatched them out of his hand, and tore them open. Everything had been successful. Lady Clementina had died quite suddenly on the night of the 17th!

His first thought was for Sybil, and he sent her off a telegram announcing his immediate return to London. He then ordered his valet to pack his things for the night mail, sent his gondoliers about five times their proper fare, and ran up to his sitting-room with a light step and a buoyant heart. There he found three letters waiting for him. One was from Sybil herself, full of sympathy and condolence. The others were from his mother, and from Lady Clementina's solicitor. It seemed that the old lady had dined with the Duchess that very night, had delighted every one by her wit and esprit, but had gone home somewhat early, complaining of heartburn. In the morning she was found dead in her bed, having apparently suffered no pain. Sir Mathew Reid had been sent for at once, but, of course, there was nothing to be done, and she was to be buried on the 22nd at Beauchamp Chalcote. A few days before she died she had made her will, and left Lord Arthur her little house in Curzon Street, and all her furniture, personal effects, and pictures, with the exception of her collection of miniatures, which was to go to her sister, Lady Margaret Rufford, and her amethyst necklace, which Sybil Merton was to have. The property was not of much value; but Mr. Mansfield, the solicitor, was extremely anxious for Lord Arthur to return at once, if possible, as there were a great many bills to be paid, and Lady Clementina had never kept any regular accounts.

Lord Arthur was very much touched by Lady Clementina's kind remembrance of him, and felt that Mr. Podgers had a great deal to answer for. His love of Sybil, however, dominated every other emotion, and the consciousness that he had done his duty gave him peace and comfort. When he arrived at Charing Cross, he felt perfectly happy.

The Mertons received him very kindly. Sybil made him promise that he would never again allow anything to come between them, and the marriage was fixed for the 7th June. Life seemed to him once more bright and beautiful, and all his old gladness came back to him again.

One day, however, as he was going over the house in Curzon Street, in company with Lady Clementina's solicitor and Sybil herself, burning packages of faded letters, and turning out drawers of odd rubbish, the young girl suddenly gave a little cry of delight.

"What have you found, Sybil?" said Lord Arthur, looking up from his work, and smiling.

"This lovely little silver bonbonnière, Arthur. Isn't it quaint and Dutch? Do give it to me! I know amethysts won't become me till I am over eighty."

It was the box that had held the aconitine.

Lord Arthur started, and a faint blush came into his cheek. He had almost entirely forgotten what he had done, and it seemed to him a curious coincidence that Sybil, 
for whose sake he had gone through all that terrible anxiety, should have been the first to remind him of it.

"Of course you can have it, Sybil. I gave it to poor Lady Clem myself."

"Oh! thank you, Arthur; and may I have the bonbon too? I had no notion that Lady Clementina liked sweets. I thought she was far too intellectual."

Lord Arthur grew deadly pale, and a horrible idea crossed his mind.

"Bonbon, Sybil? What do you mean?" he said in a slow, hoarse voice.

"There is one in it, that is all. It looks quite old and dusty, and I have not the slightest intention of eating it. What is the matter, Arthur? How white you look!"

Lord Arthur rushed across the room, and seized the box. Inside it was the ambercoloured capsule, with its poison-bubble. Lady Clementina had died a natural death after all!

The shock of the discovery was almost too much for him. He flung the capsule into the fire, and sank on the sofa with a cry of despair.

\section{Chapter V}

MR. Merton was a good deal distressed at the second postponement of the marriage, and Lady Julia, who had already ordered her dress for the wedding, did all in her power to make Sybil break off the match. Dearly, however, as Sybil loved her mother, she had given her whole life into Lord Arthur's hands, and nothing that Lady Julia could say could make her waver in her faith. As for Lord Arthur himself, it took him days to get over his terrible disappointment, and for a time his nerves were completely unstrung. His excellent common sense, however, soon asserted itself, and his sound, practical mind did not leave him long in doubt about what to do. Poison having proved a complete failure, dynamite, or some other form of explosive, was obviously the proper thing to try.

He accordingly looked again over the list of his friends and relatives, and, after careful consideration, determined to blow up his uncle, the Dean of Chichester. The Dean, who was a man of great culture and learning, was extremely fond of clocks, and had a wonderful collection of timepieces, ranging from the fifteenth century to the present day, and it seemed to Lord Arthur that this hobby of the good Dean's offered him an excellent opportunity for carrying out his scheme. Where to procure an explosive machine was, of course, quite another matter. The London Directory gave him no information on the point, and he felt that there was very little use in going to Scotland Yard about it, as they never seemed to know anything about the movements of the dynamite faction till after an explosion had taken place, and not much even then.

Suddenly he thought of his friend Rouvaloff, a young Russian of very revolutionary tendencies, whom he had met at Lady Windermere's in the winter. Count Rouvaloff was supposed to be writing a life of Peter the Great, and to have come over to England for the purpose of studying the documents relating to that Tsar's residence 
in this country as a ship carpenter; but it was generally suspected that he was a Nihilist agent, and there was no doubt that the Russian Embassy did not look with any favour upon his presence in London. Lord Arthur felt that he was just the man for his purpose, and drove down one morning to his lodgings in Bloomsbury, to ask his advice and assistance.

"So you are taking up politics seriously?" said Count Rouvaloff, when Lord Arthur had told him the object of his mission; but Lord Arthur, who hated swagger of any kind, felt bound to admit to him that he had not the slightest interest in social questions, and simply wanted the explosive machine for a purely family matter, in which no one was concerned but himself.

Count Rouvaloff looked at him for some moments in amazement, and then seeing that he was quite serious, wrote an address on a piece of paper, initialled it, and handed it to him across the table.

"Scotland Yard would give a good deal to know this address, my dear fellow."

"They shan't have it," cried Lord Arthur, laughing; and after shaking the young Russian warmly by the hand he ran downstairs, examined the paper, and told the coachman to drive to Soho Square.

There he dismissed him, and strolled down Greek Street, till he came to a place called Bayle's Court. He passed under the archway, and found himself in a curious cul-de-sac, that was apparently occupied by a French Laundry, as a perfect network of clothes-lines was stretched across from house to house, and there was a flutter of white linen in the morning air. He walked right to the end, and knocked at a little green house. After some delay, during which every window in the court became a blurred mass of peering faces, the door was opened by a rather rough-looking foreigner, who asked him in very bad English what his business was. Lord Arthur handed him the paper Count Rouvaloff had given him. When the man saw it he bowed, and invited Lord Arthur into a very shabby front parlour on the ground floor, and in a few moments Herr Winckelkopf, as he was called in England, bustled into the room, with a very wine-stained napkin round his neck, and a fork in his left hand.

"Count Rouvaloff has given me an introduction to you," said Lord Arthur, bowing, "and I am anxious to have a short interview with you on a matter of business. My name is Smith, Mr. Robert Smith, and I want you to supply me with an explosive clock."

"Charmed to meet you, Lord Arthur," said the genial little German, laughing. "Don't look so alarmed, it is my duty to know everybody, and I remember seeing you one evening at Lady Windermere's. I hope her ladyship is quite well. Do you mind sitting with me while I finish my breakfast? There is an excellent pâté, and my friends are kind enough to say that my Rhine wine is better than any they get at the German Embassy," and before Lord Arthur had got over his surprise at being recognised, he found himself seated in the back-room, sipping the most delicious Marcobrünner out of a pale yellow hock-glass marked with the Imperial monogram, and chatting in the friendliest manner possible to the famous conspirator. 
"Explosive clocks," said Herr Winckelkopf, "are not very good things for foreign exportation, as, even if they succeed in passing the Custom House, the train service is so irregular, that they usually go off before they have reached their proper destination. If, however, you want one for home use, I can supply you with an excellent article, and guarantee that you will he satisfied with the result. May I ask for whom it is intended? If it is for the police, or for any one connected with Scotland Yard, I am afraid I cannot do anything for you. The English detectives are really our best friends, and I have always found that by relying on their stupidity, we can do exactly what we like. I could not spare one of them."

"I assure you," said Lord Arthur, "that it has nothing to do with the police at all. In fact, the clock is intended for the Dean of Chichester."

"Dear me! I had no idea that you felt so strongly about religion, Lord Arthur. Few young men do nowadays."

"I am afraid you overrate me, Herr Winckelkopf," said Lord Arthur, blushing. "The fact is, I really know nothing about theology."

"It is a purely private matter then?"

"Purely private."

Herr Winckelkopf shrugged his shoulders, and left the room, returning in a few minutes with a round cake of dynamite about the size of a penny, and a pretty little French clock, surmounted by an ormolu figure of Liberty trampling on the hydra of Despotism.

Lord Arthur's face brightened up when he saw it. "That is just what I want," he cried, "and now tell me how it goes off."

"Ah! There is my secret," answered Herr Winckelkopf, contemplating his invention with a justifiable look of pride; "let me know when you wish it to explode, and I will set the machine to the moment."

"Well, today is Tuesday, and if you could send it off at once -"

"That is impossible; I have a great deal of important work on hand for some friends of mine in Moscow. Still, I might send it off tomorrow."

"Oh, it will be quite time enough!" said Lord Arthur politely, "if it is delivered tomorrow night or Thursday morning. For the moment of the explosion, say Friday at noon exactly. The Dean is always at home at that hour."

"Friday, at noon," repeated Herr Winckelkopf, and he made a note to that effect in a large ledger that was lying on a bureau near the fireplace.

"And now," said Lord Arthur, rising from his seat, "pray let me know how much I am in your debt."

"It is such a small matter, Lord Arthur, that I do not care to make any charge. The dynamite comes to seven and sixpence, the clock will be three pounds ten, and the carriage about five shillings. I am only too pleased to oblige any friend of Count Rouvaloff's."

"But your trouble, Herr Winckelkopf?" 
"Oh, that is nothing! It is a pleasure to me. I do not work for money; I live entirely for my art."

Lord Arthur laid down $£ 4,2 \mathrm{~s}$. $6 \mathrm{~d}$. on the table, thanked the little German for his kindness, and, having succeeded in declining an invitation to meet some Anarchists at a meat-tea on the following Saturday, left the house and went off to the Park.

For the next two days he was in a state of the greatest excitement, and on Friday at twelve o'clock he drove down to the Buckingham to wait for news. All the afternoon the stolid hall-porter kept posting up telegrams from various parts of the country giving the results of horse-races, the verdicts in divorce suits, the state of the weather, and the like, while the tape ticked out wearisome details about an all-night sitting in the House of Commons, and a small panic on the Stock Exchange. At four o'clock the evening papers came in, and Lord Arthur disappeared into the library with the Pall Mall, the St. James's, the Globe, and the Echo, to the immense indignation of Colonel Goodchild, who wanted to read the reports of a speech he had delivered that morning at the Mansion House, on the subject of South African Missions, and the advisability of having black Bishops in every province, and for some reason or other had a strong prejudice against the Evening News. None of the papers, however, contained even the slightest allusion to Chichester, and Lord Arthur felt that the attempt must have failed. It was a terrible blow to him, and for a time he was quite unnerved. Herr Winckelkopf, whom he went to see the next day was full of elaborate apologies, and offered to supply him with another clock free of charge, or with a case of nitro-glycerine bombs at cost price. But he had lost all faith in explosives, and Herr Winckelkopf himself acknowledged that everything is so adulterated nowadays, that even dynamite can hardly be got in a pure condition. The little German, however, while admitting that something must have gone wrong with the machinery, was not without hope that the clock might still go off, and instanced the case of a barometer that he had once sent to the military Governor at Odessa, which, though timed to explode in ten days, had not done so for something like three months. It was quite true that when it did go off, it merely succeeded in blowing a housemaid to atoms, the Governor having gone out of town six weeks before, but at least it showed that dynamite, as a destructive force, was, when under the control of machinery, a powerful, though a somewhat unpunctual agent. Lord Arthur was a little consoled by this reflection, but even here he was destined to disappointment, for two days afterwards, as he was going upstairs, the Duchess called him into her boudoir, and showed him a letter she had just received from the Deanery.

"Jane writes charming letters," said the Duchess; "you must really read her last. It is quite as good as the novels Mudie sends us."

Lord Arthur seized the letter from her hand. It ran as follows:-

THE DEANERY, CHICHESTER, 27th May.

My Dearest Aunt, 
Thank you so much for the flannel for the Dorcas Society, and also for the gingham. I quite agree with you that it is nonsense their wanting to wear pretty things, but everybody is so Radical and irreligious nowadays, that it is difficult to make them see that they should not try and dress like the upper classes. I am sure I don't know what we are coming to. As papa has often said in his sermons, we live in an age of unbelief.

We have had great fun over a clock that an unknown admirer sent papa last Thursday. It arrived in a wooden box from London, carriage paid, and papa feels it must have been sent by some one who had read his remarkable sermon, "Is Licence Liberty?" for on the top of the clock was a figure of a woman, with what papa said was the cap of Liberty on her head. I didn't think it very becoming myself, but papa said it was historical, so I suppose it is all right. Parker unpacked it, and papa put it on the mantelpiece in the library, and we were all sitting there on Friday morning, when just as the clock struck twelve, we heard a whirring noise, a little puff of smoke came from the pedestal of the figure, and the goddess of Liberty fell off, and broke her nose on the fender! Maria was quite alarmed, but it looked so ridiculous, that James and I went off into fits of laughter, and even papa was amused. When we examined it, we found it was a sort of alarum clock, and that, if you set it to a particular hour, and put some gunpowder and a cap under a little hammer, it went off whenever you wanted. Papa said it must not remain in the library, as it made a noise, so Reggie carried it away to the schoolroom, and does nothing but have small explosions all day long. Do you think Arthur would like one for a wedding present? I suppose they are quite fashionable in London. Papa says they should do a great deal of good, as they show that Liberty can't last, but must fall down. Papa says Liberty was invented at the time of the French Revolution. How awful it seems!

I have now to go to the Dorcas, where I will read them your most instructive letter. How true, dear aunt, your idea is, that in their rank of life they should wear what is unbecoming. I must say it is absurd, their anxiety about dress, when there are so many more important things in this world, and in the next. I am so glad your flowered poplin turned out so well, and that your lace was not torn. I am wearing my yellow satin, that you so kindly gave me, at the Bishop's on Wednesday, and think it will look all right. Would you have bows or not? Jennings says that every one wears bows now, and that the underskirt should be frilled. Reggie has just had another explosion, and papa has ordered the clock to be sent to the stables. I don't think papa likes it so much as he did at first, though he is very flattered at being sent such a pretty and ingenious toy. It shows that people read his sermons, and profit by them.

Papa sends his love, in which James, and Reggie, and Maria all unite, and, hoping that Uncle Cecil's gout is better, believe me, dear aunt, ever your affectionate niece,

JANE PERCY.

PS. - Do tell me about the bows. Jennings insists they are the fashion.

Lord Arthur looked so serious and unhappy over the letter, that the Duchess went into fits of laughter.

"My dear Arthur," she cried, "I shall never show you a young lady's letter again! But what shall I say about the clock? I think it is a capital invention, and I should like to have one myself."

"I don't think much of them," said Lord Arthur, with a sad smile, and, after kissing his mother, he left the room. 
When he got upstairs, he flung himself on a sofa, and his eyes filled with tears. He had done his best to commit this murder, but on both occasions he had failed, and through no fault of his own. He had tried to do his duty, but it seemed as if Destiny herself had turned traitor. He was oppressed with the sense of the barrenness of good intentions, of the futility of trying to be fine. Perhaps, it would be better to break off the marriage altogether. Sybil would suffer, it is true, but suffering could not really mar a nature so noble as hers. As for himself, what did it matter? There is always some war in which a man can die, some cause to which a man can give his life, and as life had no pleasure for him, so death had no terror. Let Destiny work out his doom. He would not stir to help her.

At half-past seven he dressed, and went down to the club. Surbiton was there with a party of young men, and he was obliged to dine with them. Their trivial conversation and idle jests did not interest him, and as soon as coffee was brought he left them, inventing some engagement in order to get away. As he was going out of the club, the hall-porter handed him a letter. It was from Herr Winckelkopf, asking him to call down the next evening, and look at an explosive umbrella, that went off as soon as it was opened. It was the very latest invention, and had just arrived from Geneva. He tore the letter up into fragments. He had made up his mind not to try any more experiments. Then he wandered down to the Thames Embankment, and sat for hours by the river. The moon peered through a mane of tawny clouds, as if it were a lion's the tide, and the railway signals changed from green to scarlet as the trains ran shrieking across the bridge. After some time, twelve o'clock boomed from the tall tower at Westminster, and at each stroke of the sonorous bell the night seemed to tremble. Then the railway lights went out, one solitary lamp left gleaming like a large ruby on a giant mast, and the roar of the city became fainter.

At two o'clock he got up, and strolled towards Blackfriars. How unreal everything looked! How like a strange dream! The houses on the other side of the river seemed built out of darkness. One would have said that silver and shadow had fashioned the world anew. The huge dome of St. Paul's loomed like a bubble through the dusky air.

As he approached Cleopatra's Needle he saw a man leaning over the parapet, and as he came nearer the man looked up, the gas-light falling full upon his face.

It was Mr. Podgers, the cheiromantist! No one could mistake the fat, flabby face, the gold-rimmed spectacles, the sickly feeble smile, the sensual mouth.

Lord Arthur stopped. A brilliant idea flashed across him, and he stole softly up behind. In a moment he had seized Mr. Podgers by the legs, and flung him into the Thames. There was a coarse oath, a heavy splash, and all was still. Lord Arthur looked anxiously over, but could see nothing of the cheiromantist but a tall hat, pirouetting in an eddy of moonlit water. After a time it also sank, and no trace of Mr. Podgers was visible. Once he thought that he caught sight of the bulky misshapen figure striking out for the staircase by the bridge, and a horrible feeling of failure came over him, but it turned out to be merely a reflection, and when the moon shone 
out from behind a cloud it passed away. At last he seemed to have realised the decree of destiny. He heaved a deep sigh of relief, and Sybil's name came to his lips.

"Have you dropped anything, sir?" said a voice behind him suddenly.

He turned round, and saw a policeman with a bull's-eye lantern.

"Nothing of importance, sergeant," he answered, smiling, and hailing a passing hansom, he jumped in, and told the man to drive to Belgrave Square.

For the next few days he alternated between hope and fear. There were moments when he almost expected Mr. Podgers to walk into the room, and yet at other times he felt that Fate could not be so unjust to him. Twice he went to the cheiromantist's address in West Moon Street, but he could not bring himself to ring the bell. He longed for certainty, and was afraid of it.

Finally it came. He was sitting in the smoking-room of the club having tea, and listening rather wearily to Surbiton's account of the last comic song at the Gaiety, when the waiter came in with the evening papers. He took up the St. James's, and was listlessly turning over its pages, when this strange heading caught his eye:

\section{SUICIDE OF A CHEIROMANTIST.}

He turned pale with excitement, and began to read. The paragraph ran as follows:

Yesterday morning, at seven o'clock, the body of Mr. Septimus R. Podgers, the eminent cheiromantist, was washed on shore at Greenwich, just in front of the Ship Hotel. The unfortunate gentleman had been missing for some days, and considerable anxiety for his safety had been felt in cheiromantic circles. It is supposed that he committed suicide under the influence of a temporary mental derangement, caused by overwork, and a verdict to that effect was returned this afternoon by the coroner's jury. Mr. Podgers had just completed an elaborate treatise on the subject of the Human Hand, that will shortly be published, when it will no doubt attract much attention. The deceased was sixty-five years of age, and does not seem to have left any relations.

Lord Arthur rushed out of the club with the paper still in his hand, to the immense amazement of the hall-porter, who tried in vain to stop him, and drove at once to Park Lane. Sybil saw him from the window, and something told her that he was the bearer of good news. She ran down to meet him, and, when she saw his face, she knew that all was well.

"My dear Sybil," cried Lord Arthur, "let us be married tomorrow!"

"You foolish boy! Why, the cake is not even ordered!" said Sybil, laughing through her tears. 


\section{Chapter VI}

WHEN the wedding took place, some three weeks later, St. Peter's was crowded with a perfect mob of smart people. The service was read in the most impressive manner by the Dean of Chichester, and everybody agreed that they had never seen a handsomer couple than the bride and bridegroom. They were more than handsome, however - they were happy. Never for a single moment did Lord Arthur regret all that he had suffered for Sybil's sake, while she, on her side, gave him the best things a woman can give to any man - worship, tenderness, and love. For them romance was not killed by reality. They always felt young.

Some years afterwards, when two beautiful children had been born to them, Lady Windermere came down on a visit to Alton Priory, a lovely old place, that had been the Duke's wedding present to his son; and one afternoon as she was sitting with Lady Arthur under a lime-tree in the garden, watching the little boy and girl as they played up and down the rose-walk, like fitful sunbeams, she suddenly took her hostess's hand in hers, and said, "Are you happy, Sybil?"

"Dear Lady Windermere, of course I am happy. Aren't you?"

"I have no time to be happy, Sybil. I always like the last person who is introduced to me; but, as a rule, as soon as I know people I get tired of them."

"Don't your lions satisfy you, Lady Windermere?"

"Oh dear, no! lions are only good for one season. As soon as their manes are cut, they are the dullest creatures going. Besides, they behave very badly, if you are really nice to them. Do you remember that horrid Mr. Podgers? He was a dreadful impostor. Of course, I didn't mind that at all, and even when he wanted to borrow money I forgave him, but I could not stand his making love to me. He has really made me hate cheiromancy. I go in for telepathy now. It is much more amusing."

"You mustn't say anything against cheiromancy here, Lady Windermere; it is the only subject that Arthur does not like people to chaff about. I assure you he is quite serious over it."

"You don't mean to say that he believes in it, Sybil?"

"Ask him, Lady Windermere, here he is"; and Lord Arthur came up the garden with a large bunch of yellow roses in his hand, and his two children dancing round him.

"Lord Arthur?"

"Yes, Lady Windermere."

"You don't mean to say that you believe in cheiromancy?"

"Of course I do," said the young man, smiling.

"But why?"

"Because I owe to it all the happiness of my life," he murmured, throwing himself into a wicker chair.

"My dear Lord Arthur, what do you owe to it?"

"Sybil," he answered, handing his wife the roses, and looking into her violet eyes. 
"What nonsense!" cried Lady Windermere. "I never heard such nonsense in all my life."

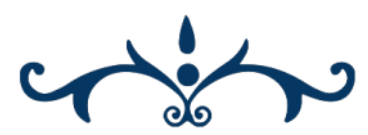

